\title{
Collaborative Strategy for the Sustainability of the Wan Abdul Rahman Forest Park (Tahura WAR ) in Supporting Ecotourism in Lampung Province
}

\author{
Rahayu Sulistiowati ${ }^{1, *}$ Suprihatin Ali $^{2}$, Christine Wulandari ${ }^{3,}$ Melya Riniarti ${ }^{4}$ \\ Selvi Diana Meilinda ${ }^{5}$ \\ ${ }^{1,5}$ Public Administration Department, Universitas Lampung \\ 2. Business Administration Department, Universitas Lampung \\ 3,4 Forestry Department, Universitas Lampung \\ "Corresponding author.Email: rahayu.sulistiowati@fisip.unila.ac.id
}

\begin{abstract}
Management of the Wan Abdul Rahman Tahura Area to be effective requires the participation and role of related parties. Community forest management partnership is one of the efforts to improve the welfare of community forest farmers. Community forest management has been identified as having great potential to improve the sustainability of the forest function. The purpose of this study is to analyze the strategy of collaboration between institutions in supporting the sustainability of Tahura Wan Abdul Rahman to support ecotourism in the province of Lampung. The inter-institutional collaborative strategy carried out for the preservation of the Tahura area in Support of Ecotourism is 1. Collaboration with relevant stakeholders in managing forest potential and ecotourism. 2 Inventory of biodiversity potential inside and outside the area and the preparation of design for natural tourism sites in the utilization zone involving the community 3 Synergizing regional development policies and programs in the buffer zone of Tahura 4 Developing community empowerment programs around Tahura by involving stakeholders from relevant institutions 5 Encouraging multi-stakeholder cooperation through multi-sectoral forums in supporting the management of the Tahura area 6 Management of tourism potential inside and outside the community-based area in a synergistic manner.
\end{abstract}

Keywords: Grand Forest Park, ecotourism, Partnership, conservation

\section{INTRODUCTION}

The Wan Abdul Rachman Tahura area in Lampung Province is one of the most vital areas as a support for economic, social and ecological life for the people of Lampung. The location of the area which has an area of $22,249.31$ hectares is surrounded by the administrative areas of Pesawaran Regency and Bandar Lampung City. Such specific landscape characteristics make the area a provider of various environmental services. for the surrounding area. On the other hand, the demographic characteristics around the area are residents of 34 villages, so it cannot be avoided that the management of ecosystems in the area is also influenced by it. At least there are approximately 5000 families outside and inside the area who depend on the Wan Abdul Rachman Tahura ecosystem for their lives.

One of the environmental services provided by Tahura WAR is tourism, especially ecotourism.
However, this type of tourism is also among those affected by the COVID-19 pandemic. However, naturebased or outdoor tourism activities are predicted to quickly rise and develop because it is a special interest tourism so that it needs to be supported by the development of ecotourism in all regions (Kemenparekraf, 2020).

Ecotourism is estimated to be the most popular tourism product after the pandemic, especially for activities with small and active groups such as outdoor interactions, nature education activities for families, to activities that contribute to nature conservation.

Encouraging the development of conservation tourism more broadly is motivated by the awareness of tourism trends that are changing from general tourism to nature tourism or ecotourism. Nature tourism provides more benefits, including direct interaction with nature, 
introduction to local culture, and awareness of the importance of nature conservation.

Seeing the existence of Tahura WAR in Lampung Province as one of the ecologically important conservation areas, its role in addition to providing economic and social benefits for the surrounding community, the management of the WAR Tahura Area to be effective requires the participation and role of related parties. Community forest management partnership is one of the efforts to improve the welfare of community forest farmers. Community forest management has been identified as having great potential to improve the sustainability of the forest function. For this reason, research is needed on how collaboration strategies between institutions are needed to preserve the Wan Abdul Rahman Forest Park (Tahura WAR) in supporting Ecotourism in Lampung Province.

\section{METHOD}

This exploratory descriptive study with a qualitative approach is intended to obtain data about existing facts and symptoms, as well as factual information that can describe the involvement of stakeholders from other relevant institutions, both government, private and community in supporting the preservation of the Tahura WAR area to support ecotourism.

Qualitatively, the data were obtained using participatory observation techniques and open interviews [1] and literature studies. Observations and interviews in the field in order to obtain data related to the involvement of stakeholders of the relevant institutions in the management of Tahura WAR. While other data used in the form of the latest scientific literature in the 2015-2021 range which has been documented in books, theses, journals, archives, and other books related to this research. The results of the qualitative data are then summarized, analyzed and synthesized in depth, which are then described descriptively and conclusions are drawn.

\section{RESULT AND ANALYSIS}

The Wan AbdulRahman Forest Park (Tahura WAR) covers the Gunung Betung Register forest area. Administratively, Tahura Wan Abdul Rachman is located in seven sub-districts, namely Teluk Betung Barat, Tanjung Karang Barat, Kemiling, Kedondong, Gedong Tataan, Way Lima, and Padang Cermin, which are divided into Bandar Lampung City and Pesawaran Regency.

Initially, the government through the Decree of the Minister of Forestry No.742/Kpts-II/1992 dated July 21, 1992, determined the area of Register 19 Gunung Betung to be a part of Tahura WAR. This decree was later updated with the Decree of the Minister of Forestry
No. 408/Kpts-II/1993 which stated that the Gunung Betung Register 19 area had changed its function from a protected forest to a conservation forest area.

Tahura WAR has a light to heavy wavy topography. There are four mountains here, namely Mount Pesawaran, Mount Chain, Mount Tangkit Ulu Padang Ratu, and Mount Betung. The most dominant plants here are merawan [Hopea mengarawan], medang [Litsea firmahoa], rasamala [Antingia excelsa], forest orchids and ferns.

The village in the largest research area is Sumber Agung Village, Kemiling District, Bandar Lampung City. The total population of Sumber Agung Village until 2019 was 3,100 people (1,700 women and 1,400 men), with a total of 925 household $(\mathrm{KK})$. The main livelihood is managing the Tahura area, livestock, and labor. Other livelihoods are traders, farming, and others.

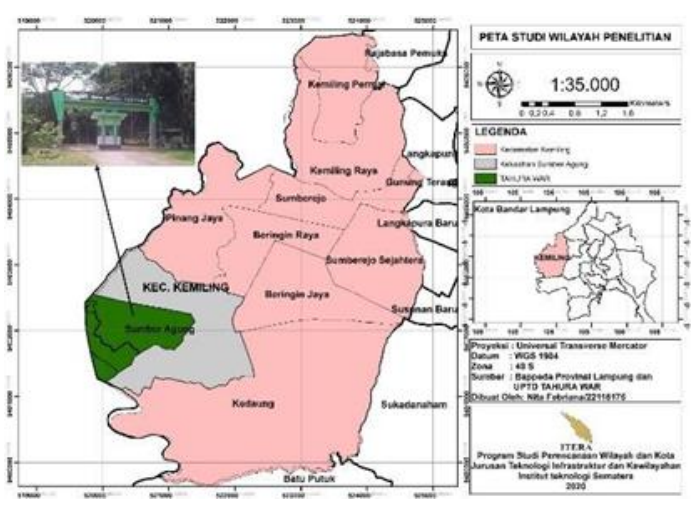

Figure 1. Map of the research area

The phenomenon that is happening about forests today, the condition of forests in Indonesia is decreasing, the threat of deforestation that cannot stop requires more attention [4]. Data from Global Forest Watch shows that tree loss in Indonesia fluctuated in 2016. This was due to the expansion of plantation land which was mostly done at the expense of forest areas. Deforestation can be defined as forest destruction or the conversion of forest functions from what should be a buffer for the world's lungs to conventional land [2]. Based on the data, it is shown that in the 2000-2005 period, Indonesia experienced a forest loss of 0.31 million hectares and then increased in the 2005-2010 period to 0.69 million hectares [3]. The case of deforestation in Indonesia has occurred since 1970. Economic factors are one of the causes of this deforestation, besides that this activity was also supported by the New Order government which took place in 1966-1998.

Forest damage in Lampung Province is not much different from forest damage in Indonesia. Lack of sense of responsibility towards forest management. Forest damage, which includes forest fires, illegal logging and others, is a form of disturbance that is increasingly occurring. The negative impacts caused by forest 
destruction are quite large, including ecological damage, decreased biodiversity, declining economic value of forests and soil productivity, changes in the micro and global climate, and smoke from forest fires disturbing public health and disrupting transportation both by land, rivers, lakes, seas. and air.

One of the conservation forests in Lampung Province is the Integrated Conservation Education Forest (HPKT) of the Wan Abdul Rachman Grand Forest Park (Tahura), which has natural areas and cultivated areas. The potential of natural resources contained in it in the form of a diversity of plants and animals, natural attractions, hills and mountains as well as rivers and creeks. The direction and purpose of the management of the Wan Abdul Rachman Tahura as a conservation area is intended to preserve natural forest areas that have a collection of plants and animals that are used for research, science, education, support cultivation, culture, tourism, and recreation (Lampung Provincial Forestry Service 2019). The management system that is not serious and what is done by the local government causes the rate of damage to the area to get worse and uncontrollable. As a conservation area, the management should be based on ecology, economy and socio-culture.

The preservation of the area's natural resources is the desire of almost all stakeholders. It can be seen from the description above that the preservation of the area as well as cooperation and collaboration are the forms of the needs of most stakeholders. Cooperation and collaboration are indispensable as a forum for improving cooperative relationships and solving problems between stakeholders in the utilization of water resource services and natural tourism in the Tahura WAR area.

Wiratno [5] is of the view that the management of national parks in Indonesia requires multi-stakeholder and multidisciplinary support, strengthened by consistent and adaptive policies by the government from the center to the field level, with intensive and targeted assistance from CSOs, local universities, community leaders, activists, and national park management staff.

Based on the results of an interview with the Head of the Tahura WAR Technical Implementation Unit [UPTD], Eny Puspasari (August 2021) it is known that currently the policy carried out by the Lampung Provincial Forestry Service is to position the community as partners to develop the Tahura WAR area, which is directed to the form of -forms of forest management and utilization in the form of: 1. Managing non-timber forest products such as; seeds, sap, fruit, leather, bamboo, rattan, medicine and so on. 2. Forest security 3. Forest protection and preservation 4 . Rehabilitation of forest areas 5. Managing forest resources that are environmental services such as; water, tourism potential development, animal breeding and cultivation of forest plants outside the area (honey bees, silkworms, resin and patchouli). More than half of the Tahura WAR area has been used as land for cultivation of crops such as cocoa, coffee, and considering the Lampung Regional Regulation No. 7 of 2000, access is given in terms of the use of non-timber forest products specifically for communities around the forest which are carried out in utilization blocks that still apply conservation principles in forest management cooperation agreements, and have an identity card for forest managers who have a forest management business period. However, the problem that arises is the lack of supervision from related parties, in this case the Lampung Provincial Forestry Service Tahura WAR, so that there are still many squatters or wild forest managers, and no doubt the area is getting damaged.

The lack of supervision carried out by the relevant agencies is caused by the minimal number of officers on duty around the area, so that only a small part of the area can be monitored, as well as the absence of clear rules governing the supervision process around the area. In addition to the problem of encroachers and illegal logging, there is also the problem of changing or shifting the boundaries of the area, resulting in uncertainty regarding the size of the area. Given the complexity of the problems faced, it is necessary to have more integrative thinking that combines problems that are ecological for the area, economic for the community and the surrounding area as well as the existing socio-cultural environment so that in the future it is hoped that management can run effectively. so that only a small part of the area can be monitored, and there are no clear rules governing the monitoring process around the area. In addition to the problem of encroachers and illegal logging, there is also the problem of changing or shifting the boundaries (PAL) of the area, resulting in uncertainty regarding the size of the area. Given the complexity of the problems faced, it is necessary to have more integrative thinking that combines problems that are ecological for the area, economic for the community and the surrounding area as well as the existing socio-cultural environment so that in the future it is hoped that management can run effectively. so that only a small part of the area can be monitored, and there are no clear rules governing the monitoring process around the area. In addition to the problem of encroachers and illegal logging, there is also the problem of changing or shifting the boundaries of the area, resulting in uncertainty regarding the size of the area. Given the complexity of the problems faced, it is necessary to have more integrative thinking that combines problems that are ecological for the area, economic for the community and the surrounding area as well as the existing socio-cultural environment so that in the future it is hoped that management can run effectively. there is also the problem of changing or shifting the boundaries of the area (PAL) resulting in 
uncertainty regarding the size of the area. Given the complexity of the problems faced, it is necessary to have more integrative thinking that combines problems that are ecological for the area, economic for the community and the surrounding area as well as the existing socio-cultural environment so that in the future it is hoped that management can run effectively. there is also the problem of changing or shifting the boundaries of the area (PAL) resulting in uncertainty regarding the size of the area. Given the complexity of the problems faced, it is necessary to have more integrative thinking that combines problems that are ecological for the area, economic for the community and the surrounding area as well as the existing socio-cultural environment so that in the future it is hoped that management can run effectively.

In line with this, through a press release from the Ministry of Forestry of the Republic of Indonesia Number: S.6333/II/PIK-1/2004, it is explained that the Minister of Forestry issued Regulation of the Minister of Forestry No. P.19/Menhut-II/2004 concerning Collaborative Management of Nature Reserve Areas and Nature Conservation Areas. This Regulation of the Minister of Forestry is intended as a general reference and basis for interested parties in the implementation of collaboration to help increase the effectiveness and benefit of the management of nature reserves and nature conservation areas for the welfare of the community. The types of activities that can be collaborated are regional planning in the form of support in accelerating regional boundaries and zoning arrangements; preparation of management plans for nature reserves and nature conservation areas;

The parties that collaborate include local community groups, individuals, NGOs in the field of conservation of biological natural resources, local governments, BUMN, BUMD, BUMS, as well as scientific institutions/educational institutions. These parties can act as initiators, facilitators or mentors. Meanwhile, support for collaboration can be in the form of human resources, facilities and infrastructure, data and information, funds or other support according to mutual agreement.

Based on this, the Lampung Provincial Forestry Service took the initiative to initiate a multi-stakeholder dialogue process based on the hopes of all parties to create a collaborative management of the Tahura WAR area that is ecologically, economically and socially integrated, and based on justice as mandated by Law no. $41 / 1997$ on forestry. This is also done by the Forestry Service in order to attract active participation from the community to be able to participate in managing the area. In general, the stages
Tourism policies in conservation areas must be regulated properly so as not to interfere with the function of the area, namely as a protected forest and limited use forest. Furthermore, for future prospects it is necessary to issue regional regulations that specifically regulate tourism, so that tourist areas can be managed professionally, in order to increase income for the surrounding community and for the area in the form of Regional Original Income. This prospect can be realized properly if the management is coordinated or program collaboration with relevant stakeholders. The type of tourism that can be developed in this research is in the form of ecotourism. The Wan Abdul Rachman Tahura area has great tourism potential, where this area has a diverse landscape,

From the results of interviews with the head of the UPTD Tahura WAR, information was obtained that Tahura WAR was indeed very potential to be used as an ecotourism location. However, there are some places that have not been developed to the fullest. The potential for ecotourism is extraordinary, many destinations have been managed or not. Data from the UPTD Tahura WAR show that currently there are managed tourist sites, such as deer breeding, the Gita Persada Butterfly Park, and a youth camp campground. Also Wijono Waterfall, Talang Rabun Waterfall, and Sinar Tiga Waterfall.

To develop ecotourism in Tahura WAR requires a strategy resulting from an analysis of internal and external factors. From the results of interviews and documentation observations, the following are these factors;

Internal Factor Analysis

A. Strengths

1. The potential of flora in the Tahura WAR area which is still relatively tight

2. Potential water sources used for community household needs

3. Natural tourism potential in the form of several waterfalls

4. The tourism potential of the area that is already known by the community

B. Weaknesses

1. Data on the potential of unique flora and fauna that can be a special attraction is still limited, so it cannot be used as material for socialization in the community.

2. The topography of the landscape, which is mostly steep and steep, becomes an obstacle for visitors who want to enjoy the potential of waterfall tourism.

3. The location of various waters in the Tahura area has not been maximally managed, including supporting 
infrastructure that can increase the comfort of visitors.

4. Not optimal coordination and cooperation of relevant stakeholders in the management of natural tourism potential in the Tahura WAR area.

5. Socialization of area management by officers is still lacking

External Factor Analysis

A. Opportunities

1. The challenges of the Lampung Provincial Government, Bandar Lampung City Government and Pesawaran Regency Government are opportunities to develop tourism potential in all regions including the Tahura WAR area.

2. The concern of the people in Sumber Agung Village for the condition of the area and the spirit of developing ecotourism.

3. There is a fairly high interest of visitors in the waterfall area and other locations to see the natural beauty of Tahura.

4. There is a Pokdarwis in the village of Sumberagung which is committed to the advancement of ecotourism,

5. There is attention from the village government on the management of tourism potential

B. Threats

1. The level of community dependence on the natural resource potential of the Tahura WAR area is still high, so it has the potential to decrease environmental quality if notgood coordination and collaboration with Tahura WAR as the manager.

2. Potential conflicts in the development of natural tourism potential and if not managed properly and involve relevant stakeholders.

3. In some locations there are steep slopes so that they are prone to landslides

SWOT analysis
Table 1 Internal Factors Analysis Summary (IFAS)

\begin{tabular}{|c|c|c|c|c|}
\hline No & Internal Strategy Factor & Weigh & Rating & Score \\
\hline & Strengths & & & \\
\hline 1 & $\begin{array}{l}\text { The condition } \\
\text { stands/vegetation in the a } \\
\text { is relatively good }\end{array}$ & $\begin{array}{l}\text { of0.098 } \\
\text { ea }\end{array}$ & 2 & 0.196 \\
\hline 2 & $\begin{array}{l}\text { Potential sources of water } \\
\text { used by the community }\end{array}$ & 0.120 & 3 & 0.360 \\
\hline 3 & $\begin{array}{l}\text { Natural tourism potential } \\
\text { the form of waterfalls } \\
\text { unspoiled conditions }\end{array}$ & $\begin{array}{l}\text { in } 0.115 \\
\text { ith }\end{array}$ & 4 & 0.460 \\
\hline 4 & $\begin{array}{l}\text { The tourism potential } \\
\text { has been } \\
\text { known to the public }\end{array}$ & lat 0.098 & 3 & 0.294 \\
\hline \multirow[t]{2}{*}{5} & $\begin{array}{l}\text { The community takes care } \\
\text { area conditions }\end{array}$ & 0.108 & 3 & 0.324 \\
\hline & AMOUNT & 0.539 & & 1,634 \\
\hline
\end{tabular}

Weaknesses

$\overline{1 \quad \text { Data }}$ on the potential for0.084 2 unique flora and fauna that can be a special attraction is still limited

2 The topography of the 0.0853 landscape is steep and steep

3 Locations of $\quad$ scattered0.098 $3 \quad 0.294$ waterfall potential

4 Coordination $\quad$ and $0.098 \quad 4 \quad 0.392$ cooperation relevant stakeholders in the management of areas lacking

$\begin{array}{lllll}5 & \text { Management socialization } & 0.096 & 3 & 0.288\end{array}$ area by officers is lacking AMOUNT

TOTAL

1,000

From the results of the analysis of internal factors in accordance with table 1, it shows that the strength factor (strengths) has a higher value than the value of the weakness factor (weaknesses), so that the strength factor can be managed optimally in order to cover weaknesses in the management of the Tahura WAR area.

Table 2. External Factors Analysis Summary (EFAS)

Factors External Strategy Weight Rating score Opportunities

$\left.\begin{array}{|l|l|l|l|}\hline \text { 1. The challenges of the } & 0.098 & 2 & 0.196 \\ \text { Lampung Provincial } \\ \text { Government, Bandar } \\ \text { Lampung City Government } \\ \text { and Pesawaran District } \\ \text { Governments are } \\ \begin{array}{l}\text { opportunities to develop } \\ \text { tourism potential in all their } \\ \text { regions including the Tahura }\end{array}\end{array}\right)$




\begin{tabular}{|l|l|l|l|}
\hline WAR area. & & & \\
\hline $\begin{array}{l}\text { 2. The community's concern } \\
\text { for the condition of the area } \\
\text { and the spirit of developing } \\
\text { ecotourism }\end{array}$ & 0.105 & 4 & 0.420 \\
\hline $\begin{array}{l}\text { 3. There is a fairly high } \\
\text { visitor interest in the } \\
\text { waterfall area and its } \\
\text { location others to see the } \\
\text { natural beauty of Tahura. }\end{array}$ & 0.096 & 3 & 0,288 \\
\hline $\begin{array}{l}\text { 4. There is a Pokdarwis in } \\
\text { the village of Sumberagung } \\
\text { that is committed to the } \\
\text { advancement of ecotourism }\end{array}$ & 0.098 & 3 & 0,294 \\
\hline $\begin{array}{l}\text { 5. There is attention from the } \\
\text { village government on the } \\
\text { management of tourism } \\
\text { potential }\end{array}$ & 0.105 & 4 & 0.420 \\
\hline $\begin{array}{l}\text { AMOUNT } \\
\text { TMOUne level of community } \\
\text { dependence on the natural } \\
\text { resource potential of the } \\
\text { Tahura WAR area is still } \\
\text { high, so it has the potential } \\
\text { to decrease environmental } \\
\text { quality if it does not } \\
\text { coordinate and collaborate } \\
\text { well with Tahura WAR as } \\
\text { the manager. }\end{array}$ & 0.105 & 3 & 0.420 \\
\hline $\begin{array}{l}\text { 2.Potential conflict in the } \\
\text { development of natural } \\
\text { tourism potential and if it is } \\
\text { not managed properly and } \\
\text { involves relevant } \\
\text { stakeholders. }\end{array}$ & 0.084 & 3 & 0.252 \\
\hline $\begin{array}{l}\text { 3.In some locations there are } \\
\text { steep slopes so that they are } \\
\text { prone to landslides }\end{array}$ & & & \\
\hline $\begin{array}{l}\text { AMOUNT } \\
\text { TOTAL }\end{array}$ & & & \\
\hline
\end{tabular}

As a mode of action, the motives of altruism cannot be categorized and standardized, but their existence is an essential marker for togetherness in a society [11]. Therefore, altruism is essential to be used as a basis for the development of urban community relations, which must be cared for and internalized as a mode of existence of a society.

Tabel 3. Tahura WAR Collaboration Strategy Based on Internal and External Environmental Analysis

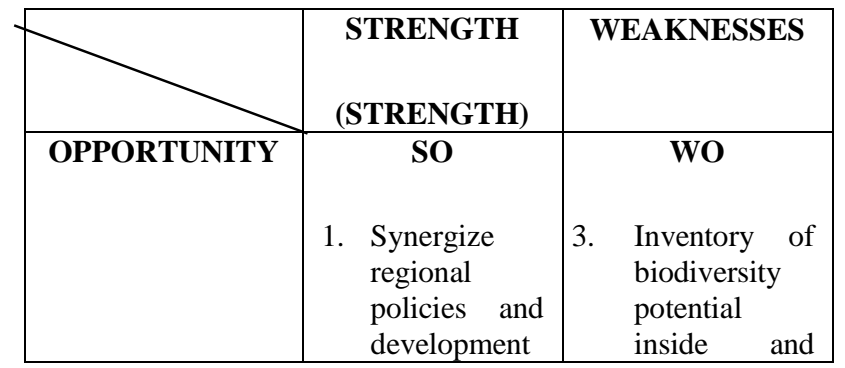

\begin{tabular}{|c|c|c|}
\hline & $\begin{array}{l}\text { in the Tahura } \\
\text { buffer area } \\
\text { with the } \\
\text { management } \\
\text { of the Tahura } \\
\text { area (S1, S2, } \\
\text { S5, O1, O2, } \\
\text { O5) } \\
\text { 2. Integration of } \\
\text { tourism } \\
\text { potential } \\
\text { management } \\
\text { inside and } \\
\text { outside } \\
\text { community- } \\
\text { based areas } \\
\text { (S1,S3, S4, } \\
\text { O1, O3, O4) } \\
\text { 3. Develop } \\
\text { community } \\
\text { empowermen } \\
\text { t programs } \\
\text { around the } \\
\text { Tahura WAR } \\
\text { area by by } \\
\text { involving } \\
\text { stakeholders } \\
\text { from related } \\
\text { institutions } \\
\text { (S2, S4, S5, } \\
\text { O2, O5) }\end{array}$ & $\begin{array}{l}\text { outside the } \\
\text { area as well as } \\
\text { preparation of } \\
\text { site design for } \\
\text { natural } \\
\text { tourism in the } \\
\text { utilization } \\
\text { zone involves } \\
\text { the } \\
\text { surrounding } \\
\text { community } \\
\text { (W1, W3, } \\
\text { W4, o1, O3, } \\
\text { O4, O5) } \\
\text { Multi- } \\
\text { stakeholder } \\
\text { cooperation in } \\
\text { supporting the } \\
\text { management } \\
\text { of the WAR } \\
\text { Tahura area } \\
\text { by forming a } \\
\text { joint forum } \\
\text { (W4, W5, O2, } \\
\text { O4, O5) }\end{array}$ \\
\hline $\begin{array}{l}\text { CHALLENGE } \\
\text { (THREATH) }\end{array}$ & $\begin{array}{l}\text { ST } \\
\text { 1. Increasing } \\
\text { environmental } \\
\text { awareness in the } \\
\text { Tahura WAR } \\
\text { area across } \\
\text { sectors (S4, S5, } \\
\text { T1, T3) } \\
\text { 2. Collaboration } \\
\text { with relevant } \\
\text { stakeholders in } \\
\text { managing the } \\
\text { potential of both } \\
\text { water resources } \\
\text { and tourism (S1, } \\
\text { S2, S3, S4, S5, } \\
\text { T2, T3) }\end{array}$ & $\begin{array}{l}\text { WT } \\
1 \text { Collaboratively } \\
\text { deal with Tahura } \\
\text { WAR disruptions } \\
\text { and disasters (W2, } \\
\text { T4, T5) }\end{array}$ \\
\hline
\end{tabular}

Table 4. Strategic Priority Scale Based on PEST . Parameters

\begin{tabular}{|ll|l|l|l|}
\hline STRATEGY & Score code & Score & $\begin{array}{l}\text { Priorit } \\
\mathrm{y}\end{array}$ \\
\hline 1. & $\begin{array}{l}\text { Synergize } \\
\text { regional } \\
\text { policies and } \\
\text { development in } \\
\text { the Tahura } \\
\text { buffer area with }\end{array}$ & O5) & & \\
\hline
\end{tabular}




\begin{tabular}{|c|c|c|c|}
\hline $\begin{array}{l}\text { the } \\
\text { management of } \\
\text { the Tahura area }\end{array}$ & & & \\
\hline $\begin{array}{l}\text { 2. management of } \\
\text { tourism potential } \\
\text { inside and outside } \\
\text { the community- } \\
\text { based area) }\end{array}$ & $\begin{array}{l}\text { (S1,S3,S4,O1,O3, } \\
\text { O4 }\end{array}$ & 1,728 & 6 \\
\hline $\begin{array}{l}3 . \quad \text { Develop } \\
\text { community } \\
\text { empowerment } \\
\text { programs around } \\
\text { the Tahura WAR } \\
\text { area by involving } \\
\text { stakeholders from } \\
\text { relevant institutions }\end{array}$ & $\begin{array}{l}(\mathrm{S} 2, \mathrm{~S} 4, \mathrm{~S} 5, \mathrm{O} 2, \\
\mathrm{O} 5)\end{array}$ & 1,818 & 4 \\
\hline $\begin{array}{l}4 . \quad \text { Increasing } \\
\text { environmental } \\
\text { awareness in the } \\
\text { Tahura WAR area } \\
\text { across sectors }\end{array}$ & $(\mathrm{S} 4, \mathrm{~S} 5, \mathrm{~T} 1, \mathrm{~T} 3)$ & 1,290 & 7 \\
\hline $\begin{array}{l}5 . \quad \text { Relevant } \\
\text { stakeholder } \\
\text { collaboration in } \\
\text { managing the } \\
\text { potential of both } \\
\text { water resources and } \\
\text { tourism ( }\end{array}$ & $\begin{array}{l}\mathrm{S} 1, \mathrm{~S} 2, \mathrm{~S} 3, \mathrm{~S} 4, \\
\mathrm{~S} 5, \mathrm{~T} 2, \mathrm{~T} 3)\end{array}$ & 2,306 & 1 \\
\hline $\begin{array}{l}6 . \quad \text { Inventory of } \\
\text { biodiversity } \\
\text { potential inside and } \\
\text { outside the area as } \\
\text { well as the } \\
\text { preparation of } \\
\text { natural tourism site } \\
\text { designs in the } \\
\text { utilization zone } \\
\text { involving the } \\
\text { surrounding } \\
\text { community ( }\end{array}$ & $\begin{array}{l}\text { W1, W3, W4, O1, } \\
\text { O3, O4, O5) }\end{array}$ & 2.052 & 2 \\
\hline $\begin{array}{l}\text { 7. Multi-stakeholder } \\
\text { cooperation in } \\
\text { supporting the } \\
\text { management of the } \\
\text { WAR Tahura area } \\
\text { by forming a joint } \\
\text { forum }\end{array}$ & $\begin{array}{l}(\mathrm{W} 4, \mathrm{~W} 5, \mathrm{O} 2, \mathrm{O} 4, \\
\mathrm{O} 5)\end{array}$ & 1,814 & 5 \\
\hline $\begin{array}{l}\text { 8. 1 Collaboratively } \\
\text { deal with Tahura } \\
\text { WAR disturbances } \\
\text { and disasters }\end{array}$ & $(\mathrm{W} 2, \mathrm{~T} 4, \mathrm{~T} 5)$ & 0.771 & 8 \\
\hline
\end{tabular}

Priority I. Relevant stakeholder collaboration in the management of ecotourism potential.

The great potential of Tahura WAR, both the potential for biodiversity, environmental services and natural tourism, really needs support, coordination, collaboration and integration of roles between stakeholders of related institutions. UPDT Tahura WAR, local governments, the private sector, communities around the Tahura WAR area have a role to play according to their respective fields in supporting sustainable and sustainable conservation area management efforts.

Forms of collaboration and cooperation in the use of water resources and tourism include:

a) Institutional strengthening in the management of water resources and natural tourism services;

b) Protection of potential areas from disturbances such as forest fires, illegal logging and erosion or flooding;

c) Development of natural tourism in collaboration with cultural tourism in the community

d) Community empowerment to manage the potential of water sources and buffer tourism must develop collaborative patterns and build community economic independence to reduce pressure on the Tahura WAR area. both economically and socially for the community and ecologically for the preservation of the Tahura WAR area.

Priority II. Inventory of the potential for biodiversity inside and outside the area as well as the preparation of design for natural tourism sites in the utilization zone involves the community

Potential inventory activities need to be carried out to increase the data collection of potential areas. This activity, which can involve the community, academics, and community groups, is expected to obtain input in the form of biophysical potential data that is useful, especially in the preparation of site design for natural tourism management.

Priority III. Synergize regional development policies and programs in the Tahura WAR buffer area with the management of the Tahura WAR UPTD

Regional development programs, especially around the Tahura WAR area, both in the development of the livestock sector, food crop agriculture, nature tourism, and protection of water catchment areas and water sources implemented through regional programs

Priority IV. Develop community empowerment programs around the Tahura WAR area by involving relevant institutional stakeholders

Community empowerment programs around the Tahura WAR area are needed in order to develop the independence and welfare of the people around the area to support the preservation of Tahura WAR. Community empowerment programs around this area need to involve related parties or institutions to be more effective.

The forms of community empowerment around the $\mathrm{TNGMb}$ area that can be done are:

1. Development of a Conservation Village that can synergize the potential of cultural tourism in the village with natural tourism within the area 
2. Providing access to people who have utilized water from within the area in a non-commercial manner

3. Granting a permit for the exploitation of natural tourism services if the tourism potential in the area has been developed.

4. Construction of tourist huts for visitor facilities

Priority V. Multi-stakeholder cooperation through the establishment of multi-sectoral forums to support the management of the WAR Tahura area

1. The low level of communication and coordination between UPTD Tahura WAR as the manager of the area and related institutional stakeholders that can have an impact on the less than optimal management of the area can be anticipated by the establishment of a multi-stakeholder forum. This forum is useful not only to build communication and coordination, but also to facilitate area management in utilizing the existing potential, both water environmental services and natural tourism, so that ecological, economic and socio-cultural synergistic management of the area can be achieved.

2. This forum needs to be initiated by the area manager, namely UPTD Tahura WAR to streamline the process of communication, discussion and sharing of information related to potential management that can be synergized both within the area and outside the area. Because this forum is not a formal institution that structurally all have the same position, it is hoped that it can solve existing problems and conflicts in a win-win solution.

Based on the observation of data in the field and the results of interviews and documentation regarding the existence of Tahura WAR for ecotourism and preserving nature, the operational strategy for managing Tahura WAR is formulated in the form of:

1. Making regulations governing the management of conservation areas specifically for Tahura

\section{Community-based ecotourism development}

3. Optimizing community and government support in the management of Tahura. Then based on the direction of the policy strategy, several policies that can be taken are obtained, namely: 1 . Reducing the squatters around the area that does not have a previous permit. 2 . Re-correcting the policies that have been made, such as giving permission to the community to carry out activities in the Tahura area which is a conservation area, even though based on Law no. 5 of 1990 it is prohibited. 3. Taking firm action against officers who have been undisciplined in the supervision process. 4 . Revoke regulations whose regulations are not in accordance with and contrary to legislation such as Perda Lampung No. 7 of 2000 concerning Retribution for Collecting Permits for Taking Non-Timber Forest Products in Forest Areas. 5. Make a detailed mapping of the area that contains blocks, both protection blocks and utilization blocks that can be used for ecotourism and other activities. 6. Develop ecotourism activities in Tahura WAR collaboratively with communities around the area. The form of community involvement is as stated in the Community Role Involvement Program Directive.

Utilization space in the Management Utilization Block of the Wan Abdul Rachman Tahura area should not only be determined from the extent of its feasibility by using an analysis of the opinions of stakeholders, but should also be able to show its feasibility in terms of the feasibility of the space in the area. In the sense that, whether the strategy applied to the area is in accordance with the existing topography or requires other conditions.

For this type of management using ecotourism strategies, there is no literature that specifically provides requirements for the suitability of the application of ecotourism in a place. Considering that each place has a variety of regional characters, both topography, landscapes, and existing soil types. However, if an area has its own charm and uniqueness, then it is very suitable for implementing ecotourism. However, Douglass (1970) in [6] gives a few principles to ecotourism managers, so that: 1. Ecotourism development must be in accordance with spatial planning. 2. Adjusting the natural potential with the development objectives 3 . As much as possible, efforts are made so that the development carried out has a dual function 4. As far as possible allocate natural areas that are not developed.

Based on the results of the analysis and synthesis of the results of the research that has been carried out, the main strategy desired is to carry out an ecotourism management strategy. It is hoped that the management can fulfill three aspects of sustainability, namely first, ecological sustainability, where in management it is hoped that the tofu environment will not be damaged and even sustainable, second, economic sustainability, where it is hoped that the ecotourism strategy can create new alternative work and business opportunities. wider area so as to improve the welfare of the local community, and thirdly socio-cultural sustainability, with the hope that the ecotourism strategy is able to maintain the culture of the local community and besides that it is also able to change the behavior of the surrounding community who are dependent on the forest for survival. However, even so, the policy does not necessarily reach the entire local community. If the authorities cannot catch the problem, it is feared that the policy will not solve the problem, it will even create new problems and will never be resolved if the government ignores it. To overcome the problem of 
cultivating (encroaching) land in the Tahura area, it is better for the government to take three alternatives as resulted from the discussion of Tahura WAR by the Lampung Nature Lovers Family (Watala), namely: 1) implementing strict conservation area rules,

\section{CONCULSION}

Conservation strategies for the preservation of the Wan Abdul Rahman Forest Park (Tahura WAR) in supporting Ecotourism in the Tahura WAR area are:

1. Collaboration of relevant stakeholders in the management of forest potential and ecotourism.

2. Inventory of the potential for biodiversity inside and outside the area as well as the preparation of design for natural tourism sites in the utilization zone involves the community

3. Synergize regional development policies and programs in the Tahura buffer area

4. Develop community empowerment programs around Tahura by involving relevant institutional stakeholders

5. Encouraging multi-stakeholder cooperation through multi-sectoral forums in supporting the management of the Tahura area

6. Management of tourism potential inside and outside the community-based area in a synergistic manner

\section{REFERENCES}

[1] Hadi, Sudharto P. (2017). Environmental Research Methodology in the Social Sector. Semarang: Undip Press.

[2] Ravikumar, A., Larson, AM, Myers, R., \& Trench, T. (2018). Inter-sectoral and multilevel coordination alone do not reduce deforestation and advance environmental justice: Why bold contestation works when collaboration fails. Environment and Planning C: Politics and Space, 1-21. doi: 10.1177/2399654418794025

[3] Margono, Arunarwati, B., Hansen, MC, Potapov, PV, Turubanova, S., \& Stolle, F. (2014). Primary forest cover loss in Indonesia over 2000-2012. Nature Climate Change, 1-6. doi: 10.1038/NCLIMATE2277

[4] Tando, Cahyoko Edi., Sudarmo, and Haryanti, Rina Herlina. (2019). Collaborative Governance as a Solution to the Case of Deforestation on the Island of Kalimantan: Literature Review. Journal of Borneo Administrator, 15(3), 257274. https://doi.org/10.24258/jba.v15i3.516

[5] Wiratno. (2018). Ten New Ways to Manage Conservation Areas in Indonesia: Building
"Learning Organizations.” Jakarta: Ministry of Environment and Forestry.

[6] C Fandeli, 2020, Fundamentals of Tourism Management, Yogyakarta: Liberty Publishers 